\title{
Factors Affect Competitiveness of Vietnamese Commercial Banks
}

\author{
Mai Thi Phuong Thuy*, Mai Binh Duong \\ Van Lang University, HCM City, Vietnam \\ Email: *thuy.mtp@vlu.edu.vn
}

How to cite this paper: Thuy, M.T.P. and Duong, M.B. (2021) Factors Affect Competitiveness of Vietnamese Commercial Banks. Open Access Library Journal, 8: e7692. https://doi.org/10.4236/oalib.1107692

Received: June 24, 2021

Accepted: July 24, 2021

Published: July 27, 2021

Copyright $\odot 2021$ by author(s) and Open Access Library Inc.

This work is licensed under the Creative Commons Attribution International License (CC BY 4.0).

http://creativecommons.org/licenses/by/4.0/

\section{(c) (i) Open Access}

\begin{abstract}
In the international integration trend, enhancing the competitive power of Vietnamese financial system in general and Vietnamese commercial banks is an important issue that has begun to be discussed in the second half of the 20th century when the wave of investment capital moves from developed countries to developing countries is flourishing. This paper provides more evidence about the macro and micro factors affecting competitiveness of Vietnamese commercial banks via Lerner ratio. Applying SGMM method of Arellano \& Bond (1991) for the panel data from 30 Vietnamese commercial banks in the period 2007-2018, the results show that the factors increasing the competitiveness of the banks are variable LERNER with one-year lag, the capital ratio (CAP), in which the credit loss provision ratio (LLP), inflation rate (INF), bank size (SIZE) have a negative effect on competitiveness.
\end{abstract}

\section{Subject Areas}

Economics

\section{Keywords}

Competitiveness, SGMM, Lerner

\section{Introduction}

In the international integration trend, enhancing the competitive power of Vietnamese financial system in general and Vietnamese commercial banks is an important issue that has begun to be discussed in the second half of the 20th century when the wave of investment capital moving from the foreign countries to developing countries is flourishing. Besides becoming a member of the World Trade Organization (WTO), the Vietnamese banking sector had undergone breakthrough innovations, going deeper into the international integration proc- 
ess, especially when a series of free trade agreements (FTA) was signed. Also, participating in the ASEAN Economic Community (AEC) and the Comprehensive and Progressive Agreement for Trans-Pacific Partnership (CPTPP) has opened many opportunities for Vietnam's banking system. The change in Vietnam's economic management mindset continues to strongly contribute to this historic trend. After integrating AEC and CPTPP, competition for human resources is expected to be fierce in the Vietnamese banking market. In addition to the undeniable benefits in access to capital, technology transfer, expert experience, etc., integration also poses many challenges for the banking industry in the process of adjustment and reform towards sustainable and stable development of the banking system.

\section{New Challenges in the Banking System}

Firstly, although the foreign commercial banks only hold a small minority of market share in Vietnamese financial and baking market, they will have almost comprehensive advantage in the future when the State's restrictions on commercial banks and foreign credit institutions are being gradually loosened according to the roadmap of implementing Vietnam's open-door commitments.

Secondly, the international economic integration increases capital transactions and risks of the banking system, while the management mechanism is incomplete, especially the inspection and supervision mechanism, and lack of close coordination, synchronization among relevant departerments. It will also bring a big challenge for Vietnamese commercial banks.

Thirdly, pressure to improve and attract high-quality financial banking human resources which is shifting to the foreign and regional organizations. During the development period, the financial sector may attract a large workforce and be one of the highest-paid, but in times of crisis and recession, labour in the financial sector is also the most vulnerable group, facing pressure to lay off or wage cut.

Even if not due to the decline in business trends, there is also an extreme labor movement in finance area. It is the cutting the low-skilled labor into replace to the high-skilled labor, this happens easily brain drain of the high-skilled labor in competition process. Therefore, one of the major challenges of the Vietnamese banking system is the retention of talents, avoiding transferring the high-quality human resources of Vietnam to regional countries.

\section{Theoretical Basis}

Commercial Bank is company, but banking operation is the special business, this is currency business and related financial services. Therefore, if rely on the level division of WEF, the competitiveness of Commercial Bank system is considered on the level of the competitiveness of the business. A company is competitive when it has ability to dominate the market, attract many customers by providing the products, services with good quality, utility, create the customer satisfaction, 
have a reputation in the market, beside that getting enough profit to maintain the sustainable development of the business.

Kazarenkova (2006) [1] defines banking competitiveness as the practical ability as well as the potential of credit institution to create and develop service products with the high competition in the market to build positive image of a reliable modern bank in responding to customer demands.

Gorditsa (2012) said that competitiveness of Commercial Banks in modern condition is determined by its responsiveness to the needs of customers and the bank's customer growth rate.

Thus, the competitiveness of a commercial bank can be understood as the ability created by bank itself based on timely grasping opportunities to maintain and develop the inherent advantages to consolidate and expand market share, enhance profit to fend off and overcome the adverse fluctuations of business environment or the pressure from competitive forces. The competitiveness of commercial bank shows the intrinsic strength of the bank itself to be able to offer products (services) to meet the needs of customer in the best way and maintain, attract customers, expand market share to increase profitability.

This research measures the competitiveness of Commercial Banks through Lerner index proposed by Lerner, A.P. (1934) [2]. This index shows the strength of a bank's market power by considering the ratio between marginal cost and price. For a perfectly competitive environment, the selling price is equal to the marginal cost, while for an environment with monopoly power, the selling price is greater than the marginal cost. Hence to measure the monopoly power, Lerner index is the method used quite commonly in the world, considering the difference between the selling price and the marginal cost [3].

$$
\text { Lerner }=\frac{P_{i, t}-M C_{i, t}}{P_{i, t}}
$$

where:

- $\quad i$ is the bank, $t$ is the time.

- $\quad P$ is the output price, calculated by total revenue over total assets.

- $\quad M C$ is the bank's marginal cost that is not observed directly. $M C$ is estimated based on the total cost function and estimated in a specific two-step sequence, specifically:

Step 1: Get the natural logarithm of the total cost function.

$$
\begin{aligned}
\ln T C_{i t}= & \alpha_{0}+\alpha_{1} \ln Q_{i t}+\frac{1}{2} \alpha_{2}\left(\ln Q_{i t}\right)^{2}+\alpha_{3} \ln w_{1 i t}+\alpha_{4} \ln w_{2 i t}+\alpha_{5} \ln w_{3 i t} \\
& +\alpha_{6} \ln Q_{i t} \ln w_{1 i t}+\alpha_{7} \ln Q_{i t} \ln w_{2 i t}+\alpha_{8} \ln Q_{i t} \ln w_{3 i t}+\alpha_{9} \ln w_{1 i t} \ln w_{2 i t} \\
& +\alpha_{10} \ln w_{1 i t} \ln w_{3 i t}+\alpha_{11} \ln w_{2 i t} \ln w_{3 i t}+\frac{1}{2} \alpha_{12}\left(\ln w_{1 i t}\right)^{2} \\
& +\frac{1}{2} \alpha_{13}\left(\ln w_{2 i t}\right)^{2}+\frac{1}{2} \alpha_{14}\left(\ln w_{3 i t}\right)^{2}+\alpha_{15} T+\frac{1}{2} \alpha_{16} T^{2} \\
& +\frac{1}{2} \alpha_{17} T \ln Q_{i t}+\alpha_{18} T \ln w_{1 i t}+\alpha_{19} T \ln w_{2 i t}+\alpha_{20} T \ln w_{3 i t}
\end{aligned}
$$


With: $T C$ is the total cost (include interest and non-interest costs); $Q$ is the total assets; three output prices include: $w_{1}$ is the cost of deposit, $w_{2}$ is the physical cost and $w_{3}$ is the labor cost; $T$ is technology change.

Step 2: After estimating the total cost function, the marginal cost is determined by taking the first derivative from Equation (2) and estimated as below:

$$
M C_{i t}=\frac{\partial T C_{i t}}{\partial Q_{i t}}=\frac{\left(\alpha_{1}+\alpha_{2} \ln Q_{i t}+\alpha_{6} \ln w_{1 i t}+\alpha_{7} \ln w_{2 i t}+\alpha_{8} \ln w_{3 i t}+\alpha_{17} T\right) T C_{i t}}{Q_{i t}}
$$

\section{Methodology}

The research identifies factors affecting to the competitiveness of Commercial Banks using the dynamic model based on the research models of Delis (2012), Nguyen et al. (2018) [4], as follows:

$$
\begin{aligned}
\text { LERNER }_{i t}= & \Phi_{0}+\Phi_{1} \text { LERNER }_{i t-1}+\Phi_{2} \mathrm{CAP}_{i t}+\Phi_{3} \mathrm{SIZE}_{i t} \\
& +\Phi_{4} \mathrm{LLP}_{i t}+\Phi_{5} \mathrm{INF}_{t}+\Phi_{6} \mathrm{GDP}_{t}+\eta_{i}+e_{i t}
\end{aligned}
$$

where: $i$ represents for bank, $t$ represents for time.

The other variables are measured through:

\begin{tabular}{ccc}
\hline Signal & Name of variable & Measure \\
\hline & Dependent variable & \\
LERNER & Indicator for measuring banking competitiveness & $\frac{P-M C}{P}$ \\
\hline CAP & Independent variable & Banking Equity \\
SIZE & Banking size & Total banking assests \\
LLP & Credit loss provision ratio & ln(Total banking asset $)_{t}$ \\
INF & Inflation rate & bad debt provision expense \\
& & Total banking assest \\
GDP & GDP growth & $\frac{\text { CPI }_{t}-\text { CPI }_{t-1}}{\text { CPI }_{t-1}}$ \\
\hline
\end{tabular}

Source: The author's proposed methodology.

We use the balanced panel data from financial statements for 30 joint stock commercial banks at Viet Nam from 2008 to 2017. We collect financial statements including balance sheet, income statement, statement of cash flows. All financial statements are collected on an annual basis and are audited.

The banks collected in the research sample include Vietnam Joint Stock Commercial Bank of Industry and Trade; Joint Stock Commercial Bank for Investment and Development of Vietnam; Joint Stock Commercial Bank for Foreign Trade of Vietnam; Asia Commercial Joint Stock Bank; An Binh Commercial Joint Stock Bank; Bao Viet Joint Stock commercial Bank; BAC A Commer- 
cial Joint Stock Bank; LienViet Commercial Joint Stock Bank; Public Vietnam Bank; DONG A Commercial Joint Stock Bank; Southeast Asia Commercial Joint Stock Bank; The Maritime Commercial Joint Stock Bank; Kien Long Commercial Joint Stock Bank; Vietnam Technological and Commercial Joint Stock Bank; Nam A Commercial Joint Stock Bank; Orient Commercial Joint Stock Bank; Military Commercial Joint Stock Bank; Vietnam International Commercial Joint Stock Bank; National Citizen bank; Sai Gon Commercial Joint Stock Bank; Saigon Bank for Industry \& Trade; Saigon-Hanoi Commercial Joint Stock Bank; Saigon Thuong Tin Commercial Joint Stock Bank; TienPhong Commercial Joint Stock Bank; Viet A Commercial Joint Stock Bank; Vietnam Commercial Joint Stock Bank for Private Enterprise; Vietnam Thuong Tin Commercial Joint Stock Bank; Petrolimex Group Commercial Joint Stock Bank; Vietnam Export Import Commercial Joint Stock; Ho Chi Minh city Development Joint Stock Commercial Bank.

The estimation method used in this paper is SGMM method (System Generalized Moment Method), this is an appropriate method for this paper with panel data has $\mathrm{T}$ small, $\mathrm{N}$ large (30 banks), which means there are few timelines but many observations. Besides that, there exists a linear relationship between dependent variables and explanatory variables. Dynamic model with one or two sides of the equation containing the variable with lag. (At the same time, the estimators of static table do not allow to create representative variables from the variables themselves in the model). The independent variables are not the strictly exogenous, means there is correlation with the residual or endogenous variable in the model. There exist separate fixed effects and heteroscedasticity or autocorrelation of the residual error.

\section{Empirical Results and Discussion}

The estimation results of factors affecting to the competitiveness of Vietnamese Commercial Banks are shown in Table 1.

The model (4) by SGMM method shows that the model does not have any defects. Specially, the autocorrelation test of residual shows that there is a first order correlation (the p-value coefficient of AR (2) is less than the significance level of 5\%) and there is no second order correlation (the p-value coefficient of AR (2) is greater than the significance level of 5\%). Both of Hansen and Sargan tests have the $\mathrm{p}$-value greater than the significance level of $5 \%$, showing that model and the representative variables used are appropriate. Based on Table 1, model estimation result (1) by GMM method shows that the regression coefficient of five variables: LERNER variable with lag (L1), the ratio of equity capital to total banking asset (CAP), Commercial Bank Size (SIZE), inflation rate (INF); Credit loss provision ratio (LLP) have affection and statistical significance to the risk of insolvency of the banks in the study sample at the significance level 5\%. The regression coefficient of these variables estimated by GMM method are also consistent with the expectation of sign. 
Table 1. The estimators of model (4) by SGMM method.

\begin{tabular}{ccccc}
\hline Independent variables & Coefficient & Std. Error & t-statistic & $\mathbf{p}>\mathbf{t}$ \\
\hline L1. & 0.26146 & 0.0542848 & 4.82 & 0.000 \\
CAP & 1.304848 & 0.061362 & 21.26 & 0.000 \\
SIZE & -0.0176386 & 0.0015922 & -11.08 & 0.000 \\
LLP & -0.5134633 & 0.0800174 & -6.42 & 0.000 \\
INF & -0.4094619 & 0.0464522 & -8.81 & 0.000 \\
GDP & 0.0305498 & 0.1689409 & 0.18 & 0.858 \\
_CONS & 0.4566929 & 0.0427708 & 10.68 & 0.000 \\
\hline
\end{tabular}

Source: Calculated from STATA 12.0 software.

Table 1 shows that the regression coefficient of competitiveness variable with lag L1 is 0.26146 , meaning statistically significant at $1 \%$ with positive sign. This shows that if the competitiveness in previous year increases, the competitiveness this year will increase. This result is consistent with the research on competitiveness of Delis (2012); Delis and Pagoulatos (2009). The regression coefficient of the equity to total assets variable (CAP) is 1.304848, has statistically significant at $1 \%$ and positive sign. This shows that if the ratio of equity capital to total assets increases, it will increase the competitiveness. The equity capital represents for the financial capacity of Commercial Banks, said that the proportion of assets financed by equity capital, the higher proportion, the higher financial autonomy, and competitiveness. Even equity capital occupies a small proportion in the business capital of banks, it has a decisive role in the existence and development of the bank. During the process of international economic integration, banks with low equity capital are more risky and easier to break than banks with high equity capital. This result is consistent with the research of Delis (2012) [5], Tabak et al., (2012) [6].

Table 1 also shows that the regression coefficient of commercial bank size variable (SIZE) is -0.0176386 and statistically significant at level $1 \%$ with negative sign. This shows that when Commercial Bank size increases, it will decrease the competitiveness of Commercial Bank. Commercial Bank size includes equity capital, mobilized capital, loan and a few other different sources, in which the saving of citizen is of the highest quality, due to low sensitivity, stability and long term, in addition, capital comes from issuing stock, bond, selling share stock to partners, strategy shareholders, internal sources. Loans from Commercial Bank, from other credit institutions ... also are the important capital in bank capital scale. Total assets increase but quality of assets is unsecure, if mainly credit balance but high bad debt, it is difficult to collect as in the past, bank will face with high credit, lead to risk of liquidity, higher risk of income, operation cost of bank increases, will decrease the competitiveness of commercial bank.

The regression coefficient of credit loss provision ratio variable (LLP) is -0.5134633 , statistically significant at level $1 \%$ with positive sign. This shows 
that credit loss provision ratio increases, it will decrease the competitiveness of Commercial Bank. This indicator shows how much percent of provision is made, reflecting negative quality of the bank's credit and low ability to collect. This ratio increases, leading to an increase in credit balance but higher bad debt, it is difficult to collect, and bank will face high risk of credit depending mainly on lending activities. The previous research show that the credit loss provision ratio (LLP) has the negative relationship with the competitiveness of Commercial Bank (Fu et al., 2014 [7]; Schaeck and Cihák, 2014 [8]).

The regression coefficient of the gross domestic product growth variable (GDP) is 0.0305498 and does not have statistically significant. This shows in Viet Nam, the gross domestic product growth has no effect on the competitiveness of Commercial Bank. The regression coefficient of inflation rate (INF) is -0.4094619 , statistically significant at level $1 \%$ and negative sign, so when inflation rate increases adversely affecting the competitiveness of the bank due to high risk in mobilizing capital, loans, investments and performing banking services. As the result, the increase of inflation leads to an increase in the bank operational expenses, reducing the competitiveness of Commercial Bank. The study result is consistent with the previous research of Delis (2012) [5]; Fernandez et al., (2005) [9].

\section{Conclusions and Implication}

The paper provides empirical evidence on the macro and micro factors affecting to the competitiveness of Commercial Bank through Lerner index, using SGMM estimation method of Arellano \& Bond (1991) [10] for balanced panel data of 30 Viet Nam Commercial Banks in period 2008-2017. The empirical research results show that factors which increase the competitiveness of banks include LERNER variable with lag (L1), the ratio of equity capital to total banking asset (CAP), in which, the credit loss provision ratio (LLP), inflation rate (INF) and bank size (SIZE) have negative effects on the competitiveness. Thereby, the paper proposes implications to enhance the competitiveness of Vietnam Commercial Bank such as: increasing equity capital ratio to improve credit quality and improve assets management efficiency.

Firstly, boost the equity ratio. This is the most important factor in ensuring the State Bank of Vietnam's minimum capital adequacy ratio as well as the safety of the bank's own operations during credit operations. Based on State Bank regulations, Vietnamese commercial banks may consider increasing charter capital through the issuance of shares to existing shareholders and domestic and foreign investors.

Secondly, boost total asset management efficiency. A commercial bank is a financial intermediary that deals in currency based on borrowed capital. Commercial banks sell the right to use deposit capital to individuals, businesses, and other economic organizations to obtain business capital. Furthermore, borrowing business capital is the most expensive expense among the bank's operating 
expenses. As a result, it has a significant impact on the bank's net income. Capital management is critical for enhancing competitive capability because it ensures that the bank always has enough capital to maintain and develop business activities at a cost level that results in optimal profits for the bank.

\section{Conflicts of Interest}

The authors declare no conflicts of interest.

\section{References}

[1] Kazarenkova. (2006) Methodical and Organizational Approaches to Management of Competitiveness of Bank in the Regional Market of Credit Services for the Population. Finance and Credit, 29, 44-49.

[2] Lerner, A.P. (1935) Economic Theory and Socialist Economy: A Rejoinder. The Review of Economic Studies, 2, 152-154. https://doi.org/10.2307/2967562

[3] Lerner, A. (1995) The Concept of Monopoly and the Measurement of Monopoly Power. In: Estrin, S. and Marin, A., Eds., Essential Readings in Economics, Palgrave, London. https://doi.org/10.1007/978-1-349-24002-9 4

[4] Nguyen, T.L., Le, A.H. and Tran, D.M. (2018) Bank Competition and Financial Stability: Empirical Evidence in Vietnam. In: Anh, L., Dong, L., Kreinovich, V. and Thach, N., Eds., Econometrics for Financial Applications, ECONVN 2018, Studies in Computational Intelligence, Vol. 760. Springer, Cham.

https://doi.org/10.1007/978-3-319-73150-6 46

[5] Delis, M.D. (2012) Bank Competition, Financial Reform, and Institutions: The Importance of Being Developed. Journal of Development Economics, 97, 450-465. https://doi.org/10.1016/j.jdeveco.2011.05.012

[6] Tabak, B.M., Fazio, D.M. and Cajueiro, D.O. (2012) The Relationship between Banking Market Competition and Risk-Taking: Do Size and Capitalization Matter? Journal of Banking \& Finance, 36, 3366-3381. https://doi.org/10.1016/j.jbankfin.2012.07.022

[7] Fu, Y., Foden, J.A., Khayter, C., Maeder, M.L., Reyon, D., Joung, J.K. and Sander, J.D. (2013) High-Frequency Off-Target Mutagenesis Induced by CRISPR-Cas Nucleases in Human Cells. Nature Biotechnology, 31, 822-826. https://doi.org/10.1038/nbt.2623

[8] Schaeck, K.C. and Cihak. (2012) Competition, Efficiency, and Stability. Banking Financial Management, 43, 215-241. https://ssrn.com/abstract=2193929 https://doi.org/10.1111/fima.12010

[9] Fernandez de Guevara, J., Maudos, J. and Perez, F. (2005) Market Power in European Banking Sectors. Journal of Financial Services Research, 27, 109-137. https://doi.org/10.1007/s10693-005-6665-Z

[10] Arellano, M. and Bover, O. (1995) Another Look at the Instrumental Variable Estimation of Error-Components Models. Journal of Econometrics, 68, 29-51. https://econpapers.repec.org/RePEc:eee:econom:v:68:y:1995:i:1:p:29-51 https://doi.org/10.1016/0304-4076(94)01642-D 